\title{
Article \\ Effect of Carbon Sources on Pyrite-Arsenopyrite Concentrate Bio-Oxidation and Growth of Microbial Population in Stirred Tank Reactors
}

\author{
Aleksandr Bulaev *, Aleksandra Nechaeva, Yuliya Elkina and Vitaliy Melamud \\ Research Center of Biotechnology of the Russian Academy of Sciences, Leninsky Ave. 33 bld. 2, \\ 119071 Moscow, Russia; nechaevasasha709@gmail.com (A.N.); yollkina@mail.ru (Y.E.); \\ vmelamud.inmi@yandex.ru (V.M.) \\ * Correspondence: bulaev-inmi@yandex.ru; Tel.: +7-499-135-04-21
}

check for

updates

Citation: Bulaev, A.; Nechaeva, A.; Elkina, Y.; Melamud, V. Effect of

Carbon Sources on Pyrite-

Arsenopyrite Concentrate Bio-

Oxidation and Growth of Microbial Population in Stirred Tank Reactors. Microorganisms 2021, 9, 2350.

https://doi.org/10.3390/

microorganisms 9112350

Academic Editor: Carlos A. Jerez

Received: 11 October 2021

Accepted: 11 November 2021

Published: 13 November 2021

Publisher's Note: MDPI stays neutral with regard to jurisdictional claims in published maps and institutional affiliations.

Copyright: (c) 2021 by the authors. Licensee MDPI, Basel, Switzerland. This article is an open access article distributed under the terms and conditions of the Creative Commons Attribution (CC BY) license (https:// creativecommons.org/licenses/by/ $4.0 /)$.

\begin{abstract}
Tank bio-oxidation is a biohydrometallurgical technology widely used for metal recovery from sulfide concentrates. Since carbon availability is one of the key factors affecting microbial communities, it may also determine the rate of sulfide concentrate bio-oxidation. The goal of the present work was to evaluate the effect of carbon sources on the bio-oxidation of the concentrate containing $56 \%$ pyrite and $14 \%$ arsenopyrite at different temperatures $\left(40\right.$ and $\left.50{ }^{\circ} \mathrm{C}\right)$ in stirred tank reactors. $\mathrm{CO}_{2}$ was supplied into the pulp of the first reactor (about $0.01 \mathrm{~L} / \mathrm{min}$ ) and $0.02 \%(w / v)$ molasses was added to the pulp of the second one, and no additional carbon sources were used in the control tests. At $40{ }^{\circ} \mathrm{C}, 77 \%$ of pyrite and $98 \%$ of arsenopyrite were oxidized in the first reactor, in the second one, $73 \%$ of pyrite and $98 \%$ of arsenopyrite were oxidized, while in the control reactor, $27 \%$ pyrite and $93 \%$ arsenopyrite were oxidized. At $50{ }^{\circ} \mathrm{C}$, in the first reactor, $94 \%$ of pyrite and $99 \%$ of arsenopyrite were oxidized, in the second one, $21 \%$ of pyrite and $94 \%$ of arsenopyrite were oxidized, while in the control reactor, $10 \%$ pyrite and $92 \%$ arsenopyrite were oxidized. The analysis of the microbial populations in the reactors revealed differences in the total number of microorganisms and their species composition. Thus, it was shown that the use of various carbon sources made it possible to increase the intensity of the concentrate bio-oxidation, since it affected microbial populations performing the process.
\end{abstract}

Keywords: biohydrometallurgy; acidophilic microorganisms; pyrite; arsenopyrite; sulfide concentrates; carbon dioxide; molasses

\section{Introduction}

Bio-oxidation of sulfide concentrates in stirred tank reactors is a biohydrometallurgical technology that allows enhancing gold recovery from refractory sulfide concentrates [1-3]. Bio-oxidation has advantages over other technologies (roasting, POX) and does not require high energy consumption and makes it possible to avoid toxic gas emissions, when processing concentrates containing arsenic [3-5]. Currently, reactor bio-oxidation accounts for about $5 \%$ of global gold production [2]. $\mathrm{BIOX}^{\circledR}, \mathrm{Bacox}^{\mathrm{TM}}$, and $\mathrm{BIONORD}^{\mathrm{TM}}$ processes are examples of commercialized bio-oxidation technologies [6-8].

Bio-oxidation processes are carried out in aerated stirred tank reactors connected in series equipped with cooling systems [3,6-8]. The biohydrometallurgical processing of sulfide concentrates is based on sulfide mineral bio-oxidation by aerobic acidophilic iron- and sulfur-oxidizing microorganisms. Industrial biohydrometallurgical processes are always carried out by mixed microbial populations, which include several species of ironand sulfur-oxidizing microorganisms $[1,3]$. The composition of microbial communities in bio-oxidation reactors depends on different factors, including the composition of the oxidized concentrate, temperature, $\mathrm{pH}$, oxygen, and carbon availability [3]. 
Bio-oxidation of sulfide minerals, components of gold-bearing concentrates (arsenopyrite, pyrite), may be described by the following simplified overall reactions [6]:

$$
\begin{gathered}
2 \mathrm{FeAsS}+7 \mathrm{O}_{2}+\mathrm{H}_{2} \mathrm{SO}_{4}+2 \mathrm{H}_{2} \mathrm{O} \rightarrow 2 \mathrm{H}_{3} \mathrm{AsO}_{4}+\mathrm{Fe}_{2}\left(\mathrm{SO}_{4}\right)_{3} \\
4 \mathrm{FeS}_{2}+15 \mathrm{O}_{2}+2 \mathrm{H}_{2} \mathrm{O} \rightarrow 2 \mathrm{Fe}_{2}\left(\mathrm{SO}_{4}\right)_{3}+2 \mathrm{H}_{2} \mathrm{SO}_{4}
\end{gathered}
$$

Reactor bio-oxidation may be performed at different temperatures using different microorganisms, but existing industrial processes are usually carried out at temperatures of $40-45^{\circ} \mathrm{C}$ since this temperature range allows achieving maximum sulfide oxidation rates and minimize cooling requirements caused by the release of heat during the bio-oxidation of minerals [3,6]. Various thermotolerant and moderately thermophilic acidophilic microorganisms usually predominate in microbial communities formed in long-term processes of sulfide concentrate bio-oxidation: bacteria of the genera Leptospirillum and Sulfobacillus, moderately thermophilic representatives of the genus Acidithiobacillus (A. caldus), as well as archaea of the family Ferroplasmaceae (genera Acidiplasma uFerroplasma) [9-24]. Despite this, long-term temperature rise in the reactors can inhibit bio-oxidation activity $[3,6]$.

Microorganisms involved in the oxidation of sulfide minerals include both autotrophs, which fix dissolved carbon dioxide using the energy obtained by the oxidation of ferrous iron and sulfur compounds, and mixo- and heterotrophs, which require organic carbon sources for stable growth, despite they also gain energy by the oxidation of inorganic compounds [1,25-27].

Differences in the properties determine interactions between microorganisms in biooxidation reactors. In particular, it was shown that between autotrophs, on the one hand, and heterotrophs and mixotrophs, on the other hand, there are trophic interactions that occur both in bioleach reactors and in natural ecosystems [11,28,29]. During the growth of autotrophic acidophiles, oxidizing ferrous iron, and sulfur, exometabolites are accumulated in the medium [30-33]. Exometabolites produced by autotrophs may be consumed by mixo- and heterotrophs as a carbon source. It should be noted that some microorganisms, which predominate in the communities of bioleach reactors, are mixo- and heterotrophs (bacteria of the genus Sulfobacillus and archaea of the family Ferroplasmaceae) and their activity depends on the presence of autotrophs (bacteria of the genus Leptospirillum and A. caldus) [1,25-27].

Since carbon availability is important for microbial populations of bioleach reactors, it may affect bio-oxidation of sulfide concentrates [3]. In a number of works, the effect of various carbon sources on the composition of microbial communities in bioleach reactors, as well as on the rate of the bio-oxidation process was studied. For example, in [11], it was shown that the composition of microbial populations of bioleach reactors connected in series changed from the first reactor to the third one due to the increase in the concentration of dissolved organic carbon, which accumulated in the reactors due to the activity of autotrophic microorganisms.

Industrial practice demonstrated that maintaining the concentration of dissolved $\mathrm{CO}_{2}$ in the medium is important to maintain the required rate of the bio-oxidation process. According to the recommendations of $\mathrm{BIOX}^{\circledR}$ developers, the concentrate should contain at least $2 \%$ carbonate to provide sufficient $\mathrm{CO}_{2}$ to promote the growth of microorganisms. If no carbonate is present in the concentrate, limestone or $\mathrm{CO}_{2}$ must be added to the primary reactors as a carbon source [6].

Besides carbon dioxide, the effect of organic substances, which can be a carbon source for mixo- and heterotrophic microorganisms, on the efficiency of the bio-oxidation process of sulfide concentrates was also investigated. In our previous work, it was shown that the rate of bio-oxidation of pyrite-arsenopyrite concentrate at $45^{\circ} \mathrm{C}$ was influenced by the addition of $0.02 \%(w / v)$ yeast extract (YE) into the medium [20]. The introduction of an organic carbon source in this case made it possible to increase the rate of oxidation of sulfide minerals. 
Thus, the results of the studies performed show that the introduction of additional carbon sources allows intensifying bio-oxidation of sulfide concentrates and affects the composition of microbial communities. At the same time, there is not enough data in the literature that allow to analyze the effect of various carbon sources on the bio-oxidation of concentrates, as well as on the composition of microbial communities. Therefore, studies on the effect of different carbon sources on the rate of sulfide concentrate bio-oxidation and on the composition of microbial communities that formed under different conditions in order to identify groups of microorganisms that can make the greatest contribution to the bio-oxidation process are of interest.

The goal of this work was to determine the effect of an additional carbon source $\left(\mathrm{CO}_{2}\right.$ and molasses) on the bio-oxidation of gold-containing pyrite-arsenopyrite flotation concentrate and growth of microbial population in stirred tank reactors at different temperatures.

\section{Materials and Methods}

\subsection{Concentrate}

The composition of the concentrate is shown in Table 1. The main sulfide minerals of the concentrate were pyrite (56\%) and arsenopyrite (14\%). In our previous work, it was shown that the concentrate is refractory since gold recovery by direct cyanidation did not exceed $57.4 \%$. It was shown that bio-oxidation in a continuous mode at $40{ }^{\circ} \mathrm{C}$ and residence time of 6 days made it possible to oxidize $70 \%$ of sulfide sulfur and increase the rate of gold recovery by cyanidation up to $83 \%$ [34].

Table 1. Chemical composition of the concentrate.

\begin{tabular}{cc}
\hline Component & Content, $\%$ \\
\hline $\mathrm{Fe}_{\text {tot }}$ & 31.8 \\
$\mathrm{Fe}_{\mathrm{s}}$ & 29.1 \\
$\mathrm{~S}_{\text {tot }}$ & 34.7 \\
$\mathrm{~S}_{\mathrm{S}}$ & 34.4 \\
$\mathrm{~S}_{\mathrm{sulfate}}$ & 0.2 \\
$\mathrm{~S}^{0}$ & 0.1 \\
$\mathrm{As}_{\text {tot }}$ & 6.9 \\
$\mathrm{As}$ & 6.5 \\
$\mathrm{Au}, \mathrm{g} / \mathrm{t}$ & 45.5 \\
\hline
\end{tabular}

\subsection{Experimental Setup and Bio-Oxidaton}

In the present work, concentrate bio-oxidation was carried out in a batch mode in $2.5 \mathrm{~L}$ reactors under the following conditions: aeration $-5 \mathrm{~L} / \mathrm{min}, 500 \mathrm{rpm}$, the temperature in the first experiment was $39-40{ }^{\circ} \mathrm{C}$, and in the second one, it was $49-50{ }^{\circ} \mathrm{C}$, the pulp density (solid to liquid ratio, S:L) was 1:5 (200 $\mathrm{g}$ of the concentrate per $1000 \mathrm{~mL}$ of liquid medium), the duration of the experiment was 40 days. The temperature in the reactors was maintained using ELMI TW-2.03 circulating water baths (Elmi, Riga, Latvia) and U-shaped titanium heat exchangers.

For the experiments, we used a liquid nutrient medium containing mineral salts (g/L): $\left(\mathrm{NH}_{4}\right)_{2} \mathrm{SO}_{4}-0.75, \mathrm{KCl}-0.05, \mathrm{MgSO}_{4} \times 7 \mathrm{H}_{2} \mathrm{O}-0.125, \mathrm{~K}_{2} \mathrm{HPO}_{4}-0.125$, distilled water-1.0 L, which was successfully used in our previous works for sulfide concentrate bio-oxidation [26,34]. The initial $\mathrm{pH}$ was adjusted by adding $5 \mathrm{~mL} / \mathrm{L}$ of $98 \%$ chemically pure sulfuric acid to the medium. After adding the concentrate to the medium, the pulp was incubated for 1 day without inoculum to stabilize the $\mathrm{pH}$.

To determine the effect of additional carbon sources on the bio-oxidation, carbon dioxide and molasses were used. $\mathrm{CO}_{2}$ was fed into the pulp of the first reactor (approximately $0.01 \mathrm{~L} / \mathrm{min}$ ) and $0.02 \%$ molasses $(w / v)$ was added to the pulp of the second reactor (at the beginning of the experiment, on days 10, 20, and 30). No additional carbon sources were added to the control reactor. 
A microbial population formed during continuous bio-oxidation of the same sulfide concentrate at $40{ }^{\circ} \mathrm{C}$ was used as inoculum, in which acidophilic bacteria Leptospitillum ferriphilum, Sulfobacillus spp., as well as archaea Ferroplasma acidiphilum and Acidiplasma sp. $[24,34]$ were predominant. The inoculum was introduced into the reactors in such a volume that the initial total number of microbial cells in the liquid phase was $\sim 1 \times 10^{8}$ cells $/ \mathrm{mL}$.

\subsection{Sampling and Analysis}

To analyze the activity of the bioleaching, samples of the liquid phase were collected every 5 days. In all samples, $\mathrm{pH}$, and redox potential (Eh) were determined using a $\mathrm{pH}-150 \mathrm{MI}$ $\mathrm{pH}$ meter (Izmeritelnaya tekhnika, Moscow, Russia), ferrous and ferric iron and arsenic concentrations were measured by trilonometric and iodometric titration, respectively $[35,36]$. Quantitative assessment of microorganisms was carried out by direct counts using an Amplival (Carl Zeiss, Jena, Germany) microscope equipped with a phase-contrast device.

After the bio-oxidation, the solid residues of bio-oxidation were separated from the liquid phase of the pulp, dried, and analyzed to determine the oxidation state of sulfide minerals. Determination of the content of iron, arsenic, and sulfur was carried out using phase analysis methods [37]. The mineral compositions of the concentrate and bio-oxidation residues were determined by X-ray diffraction using a DRON-2 diffractometer (Burevestnik, St. Petersburg, Russia).

\subsection{Microbial Population Analysis}

The analysis of the composition of microbial communities that formed under the experimental conditions was carried out by high-throughput sequencing on the MiSeq system (Illumina, San Diego, CA, USA). For analysis, pulp samples were taken from biooxidation reactors $(25 \mathrm{~mL})$ at 20,30 , and 40 days of the experiment. The biomass from the liquid phase of the pulp was collected using an Allegra X-22 centrifuge (Beckman Coulter, Indianapolis, IN, USA). To collect the biomass from the pulp sample, the solid phase was first separated by centrifugation at $1000 \mathrm{rpm}(103 \times g)$, and then the biomass was precipitated from the supernatant by centrifugation at $9500 \mathrm{rpm}(9299 \times \mathrm{g})$. Biomass preparation, DNA isolation, library preparation based on the V3-V4 region of the $16 \mathrm{~S}$ rRNA gene, amplicon preparation, sequencing on the MiSeq system (Illumina, San Diego, CA, USA) were performed as described previously $[23,38]$.

\subsection{Data Processing}

Chemical analyses used in the work were performed in duplicate. Processing of the results was carried out using the MS 15.0.459.1506 Excel 2013 software (Microsoft, Redmond, WA, USA).

\section{Results}

\subsection{Bio-Oxidation under Mesophilic Conditons}

The results of the experiment on the concentrate bio-oxidation at $40{ }^{\circ} \mathrm{C}$ are shown in Figures 1 and 2, as well as in Tables 2 and 3.

\subsubsection{Liquid Phase Analysis}

Figure 1 shows changes in the liquid phase parameters at $40^{\circ} \mathrm{C}$. The presented curves demonstrate that, at $40^{\circ} \mathrm{C}$, carbon dioxide influenced the bio-oxidation to a greater extent than the addition of molasses.

The $\mathrm{pH}$ values of the liquid phase in reactors 1 (carbon dioxide) and 2 (molasses) sharply decreased. After 10 days of bio-oxidation, the $\mathrm{pH}$ in reactor 1 decreased from 1.31 to 0.65 on the 19 th day. Then, the $\mathrm{pH}$ in the reactor was maintained by adding $\mathrm{CaCO}_{3}$ to avoid inhibiting bio-oxidation due to too high acidity. After 25 days of bio-oxidation, the $\mathrm{pH}$ value was stabilized in the range 1.13-1.43 (Figure 1a, curve 1). In reactor 2, in which the medium was supplemented with molasses, the $\mathrm{pH}$ reached a minimum on the 22nd day and was 1.08, after which it was stabilized in the range of 1.11-1.37 (Figure 1a, curve 
2). In reactor 3 , where no additional carbon sources were used, the $\mathrm{pH}$ was stabilized at a level of 1.26-1.55. All reactors required $\mathrm{CaCO}_{3}$ addition to maintain the $\mathrm{pH}$ level. In reactor 1 , the $\mathrm{CaCO}_{3}$ consumption was $314 \mathrm{~kg} / \mathrm{t}$ of the concentrate, while in reactors 2 and 3 the consumption comprised 292 and $71 \mathrm{~kg} / \mathrm{t}$, respectively.

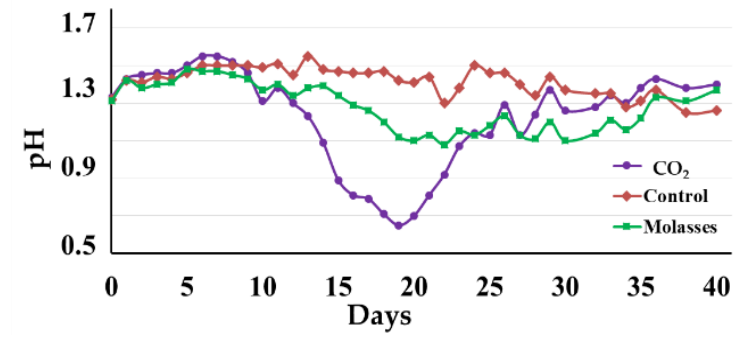

(a)

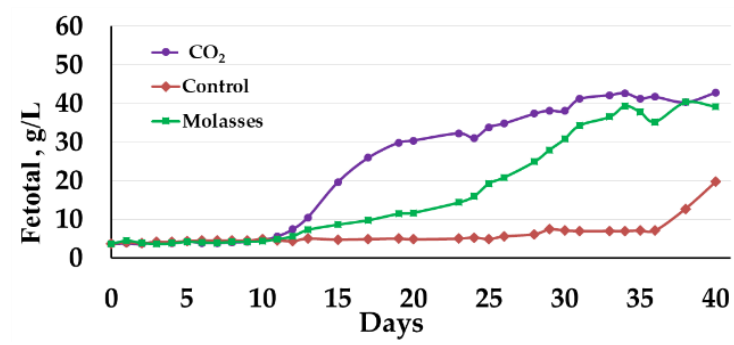

(c)

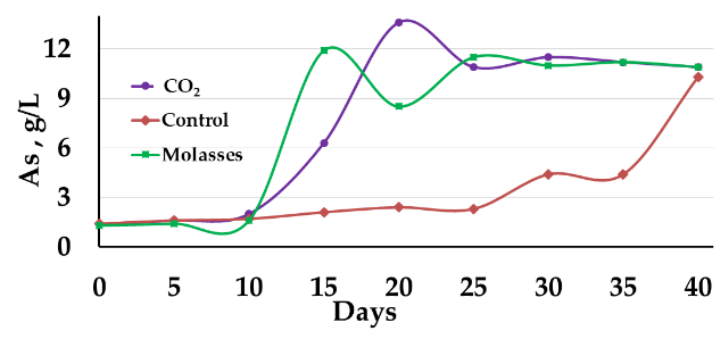

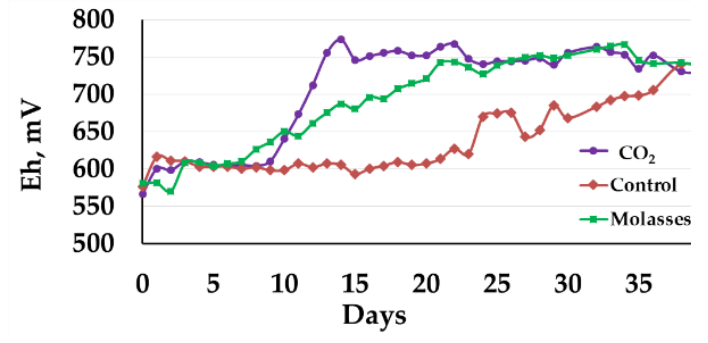

(b)

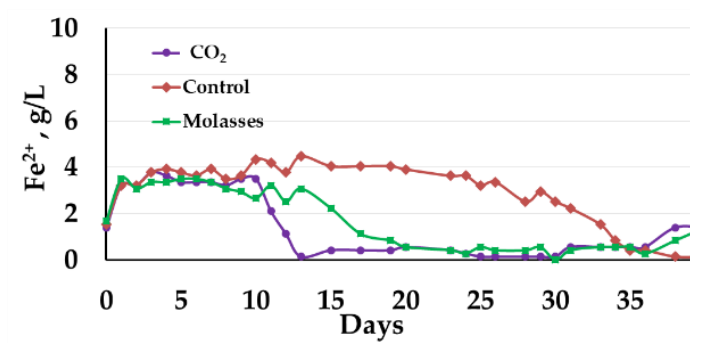

(d)

(e)

Figure 1. Changes in the liquid phase parameters during the bio-oxidation of the concentrate at $40{ }^{\circ} \mathrm{C}:(\mathbf{a})-\mathrm{pH} ;(\mathbf{b})-$ Eh; (c) - total concentration of $\mathrm{Fe}^{3+}$ and $\mathrm{Fe}^{2+}$ ions (g/L); (d)—concentration of $\mathrm{Fe}^{2+}$ ions (g/L); (e)—concentration of $\operatorname{arsenic}(\mathrm{g} / \mathrm{L})$.

Changes in the Eh (Figure 1b), which reflect the activity of oxidation of iron ions in the medium, corresponded to changes in $\mathrm{pH}$ level (Figure 1a). In reactor 1, the Eh value began to grow rapidly after 10 days and reached $755 \mathrm{mV}$ on the 13th day of bio-oxidation, and then it was in the range of 730-770 $\mathrm{mV}$ (Figure 1b, curve 1). In reactor 2, Eh reached the value of $750 \mathrm{mV}$ on the 21st day of bio-oxidation and then was in the range of 727-766 mV (Figure $1 \mathrm{~b}$, curve 2). In reactor 3 , the Eh values during almost the entire experiment were significantly lower than in reactors 1 and 2 and did not exceed $610 \mathrm{mV}$ for up to 20 days, after which Eh began to grow rapidly and by the end of the experiment, it was practically equal to the values in reactors 1 and 2 (Figure 1a).

The diagrams in Figure 1c,d show changes in the concentration of iron ions. Up to the 10th day of bio-oxidation, the total concentration of iron ions practically did not increase in all reactors (Figure 1c, curves 1-3), while the concentration of $\mathrm{Fe}^{2+}$ ions increased in all reactors (Figure 1d, curves 1-3). This indicates that in the first 10 days of the experiment, the bio-oxidation activity was low, and there was an accumulation of ferrous iron ions in the medium due to the chemical oxidation of the concentrate minerals by $\mathrm{Fe}^{3+}$ ions, which were introduced into the medium with the inoculum.

$$
\mathrm{FeS}_{2}+14 \mathrm{Fe}^{3+}+8 \mathrm{H}_{2} \mathrm{O} \rightarrow 15 \mathrm{Fe}^{2+}+16 \mathrm{H}^{+}+2 \mathrm{SO}_{4}^{2-}
$$




$$
\mathrm{FeAsS}+5 \mathrm{Fe}^{3+} \rightarrow \mathrm{S}^{0}+\mathrm{As}^{3+}+6 \mathrm{Fe}^{2+}
$$

After 10 days, in reactors 1 and 2, the total concentration of ferric and ferrous ions in the medium increased at a high rate (Figure 1c, curves 1 and 2). In reactor 1, the concentration was close to the maximum on the 31st day of bio-oxidation, reaching $40.60 \mathrm{~g} / \mathrm{L}$, after which it did not change significantly (Figure 1c, curve 1 ). In reactor 2 , the rate of increase in the concentration of iron ions was lower, and the concentration was practically equal to that in reactor 1 by the end of the experiment, on day 37 (Figure 1c, curve 2). It should be noted that in reactors 1 and 2, ferrous iron in the medium was oxidized, and its concentrations became insignificant after 13 and 20 days, respectively, slightly increasing only at the end of the experiment (Figure 1d, curves 1 and 2). In control reactor 3, the total concentration of iron $\mathrm{Fe}^{3+}$ and $\mathrm{Fe}^{2+}$ ions in the medium grew slowly to 36 days from 3.60 to $7.15 \mathrm{~g} / \mathrm{L}$. After the 37th day and up to the 40th day, the concentration sharply increased from 7.15 to $19.00 \mathrm{~g} / \mathrm{L}$ (Figure 1c, curve 3). At the same time, the concentration of $\mathrm{Fe}^{2+}$ ions in the medium in reactor 3 was higher than $1 \mathrm{~g} / \mathrm{L}$ until 34 days and then decreased to trace values (Figure 1d, curve 3).

The dynamics of changes in the concentration of arsenic in the medium differed from the dynamics of changes in the concentration of iron ions (Figure 1e). In reactors 1 and 2 , the arsenic concentration began to increase after 10 days of bio-oxidation, reaching a maximum at 15th and 20th days (13.6 and $11.9 \mathrm{~g} / \mathrm{L}$ ), respectively (Figure 1e, curves 1 and 2). Then the concentration of arsenic in the medium fluctuated. This can be explained by the fact that during sulfide concentrate bio-oxidation, the concentration of arsenic in the medium can both increase due to bioleaching of arsenopyrite (Equation (1)) and decrease due to the formation of scorodite according to Equation (5) [39]:

$$
2 \mathrm{H}_{3} \mathrm{AsO}_{4}+\mathrm{Fe}_{2}\left(\mathrm{SO}_{4}\right)_{3} \rightarrow 2 \mathrm{FeAsO}_{4} \downarrow+3 \mathrm{H}_{2} \mathrm{SO}_{4}
$$

In reactor 3, the concentration of arsenic in the medium increased slowly until the 25th day of the experiment, increasing from 1.4 to $2.3 \mathrm{~g} / \mathrm{L}$, after which it began to increase rapidly, reaching $10.3 \mathrm{~g} / \mathrm{L}$ by the end of the experiment.

\subsubsection{Solid Residue Analysis}

It was shown that the oxidation of sulfide sulfur was the highest in reactor 1 ; it was slightly lower in reactor 2 , while in reactor 3 it was approximately two times lower (Tables 3 and 4). The oxidation rate of arsenopyrite was almost equal in reactors 1 and 2, and insignificantly lower in reactor 3 . At the same time, the rate of pyrite oxidation differed (Tables 3 and 4 ).

This may be due to that arsenopyrite is more easily oxidized than pyrite, and when it is oxidized in a mixture of arsenopyrite and pyrite, electrochemical interactions occur between the minerals, which accelerate the oxidation of arsenopyrite [40,41]. In addition, it should be noted that the rapid oxidation of pyrite requires a higher Eh than arsenopyrite [41,42], while in reactor 3, Eh was lower throughout almost the entire experiment than in reactors 1 and 2 (Figure 1b). Thus, even less intense bio-oxidation of the concentrate in the control reactor made it possible to oxidize arsenopyrite at a rather high rate, while differences in the bio-oxidation activity influenced pyrite oxidation to a greater extent.

\begin{tabular}{|c|c|c|c|c|c|c|c|}
\hline Temperature & Carbon Source & $\mathrm{pH}$ & Eh & $\mathrm{Fe}^{3+}, \mathrm{g} / \mathrm{L}$ & $\mathrm{Fe}^{2+}, \mathrm{g} / \mathrm{L}$ & As, g/L & $\begin{array}{l}\text { Microbial Cell Number, } \\
\times 10^{7} \text { Cell } / \mathrm{mL}\end{array}$ \\
\hline \multirow{3}{*}{$40^{\circ} \mathrm{C}$} & $\mathrm{CO}_{2}$ & 1.40 & 730 & 41.4 & 1.4 & 10.9 & 60 \\
\hline & Molasses & 1.37 & 736 & 37.8 & 1.4 & 10.9 & 110 \\
\hline & Control & 1.26 & 730 & 19.6 & 0.1 & 10.3 & 33 \\
\hline \multirow{3}{*}{$50{ }^{\circ} \mathrm{C}$} & $\mathrm{CO}_{2}$ & 1.72 & 753 & 56.0 & 1.8 & 12.0 & 24 \\
\hline & Molasses & 1.55 & 667 & 8.1 & 1.7 & 3.0 & 22 \\
\hline & Control & 1.36 & 662 & 5.7 & 2.3 & 2.1 & 12 \\
\hline
\end{tabular}

Table 2. Parameters of the liquid phase of the pulp at the end of the experiment (on the 40th day). 
Table 3. Chemical composition of bio-oxidation residues.

\begin{tabular}{ccccccc}
\hline \multirow{2}{*}{ Mineral } & \multicolumn{5}{c}{ Content, \% } \\
\cline { 2 - 6 } & \multicolumn{5}{c}{$\mathbf{4 0}{ }^{\circ} \mathbf{C}$} & $\mathbf{5 0}^{\circ} \mathbf{C}$ \\
\cline { 2 - 6 } & Reactor 1 & Reactor 2 & Reactor 3 & Reactor 1 & Reactor 2 & Reactor 3 \\
\hline Fe $_{\text {tot }}$ & 7.20 & 8.50 & 24.50 & 3.90 & 24.50 & 26.10 \\
$\mathrm{Fe}_{\mathrm{s}}$ & 8.62 & 16.28 & 27.00 & 1.60 & 20.37 & 22.57 \\
$\mathrm{~S}_{\text {tot }}$ & 20.10 & 19.90 & 31.40 & 16.20 & 28.50 & 29.90 \\
$\mathrm{~S}_{\mathrm{s}}$ & 7.60 & 8.80 & 27.40 & 2.30 & 24.50 & 26.50 \\
$\mathrm{~S}_{\text {sulfate }}$ & 12.10 & 10.70 & 3.60 & 13.70 & 3.50 & 2.90 \\
$\mathrm{~S}^{0}$ & 0.40 & 0.40 & 0.40 & 0.10 & 0.50 & 0.50 \\
$\mathrm{As}_{\text {tot }}$ & 0.21 & 0.26 & 1.20 & 0.85 & 5.30 & 5.85 \\
$\mathrm{As}_{\mathrm{s}}$ & 0.14 & 0.16 & 0.57 & 0.03 & 0.41 & 0.47 \\
\hline
\end{tabular}

Table 4. Oxidation of sulfide minerals and sulfide sulfur after 40 days of bio-oxidation.

\begin{tabular}{cccccc}
\hline \multirow{2}{*}{ Temperature } & Carbon Source & Yield, $\%$ & \multicolumn{3}{c}{ Oxidation Rate, $\%$} \\
\cline { 3 - 6 } & & & $\mathbf{S}_{\mathbf{S}}$ & Pyrite & Arsenopyrite \\
\hline \multirow{3}{*}{$40{ }^{\circ} \mathrm{C}$} & $\mathrm{CO}_{2}$ & 85.3 & 81 & 77 & 98 \\
& Molasses & 85.9 & 78 & 73 & 98 \\
& Control & 78.7 & 37 & 27 & 93 \\
\hline \multirow{3}{*}{$50{ }^{\circ} \mathrm{C}$} & $\mathrm{CO}_{2}$ & 73.7 & 95 & 94 & 99 \\
& Molasses & 98.7 & 29 & 21 & 94 \\
& Control & 103.9 & 19 & 10 & 92 \\
\hline
\end{tabular}

It should be noted that the mass yield of the solid residue of the concentrate biooxidation in reactors 1 and 2 was higher than in reactor 3 , despite the more intense biooxidation. Obviously, this was due to the formation of calcium sulfate precipitate, which is formed when calcium carbonate is added into the medium containing sulfuric acid to maintain the $\mathrm{pH}$ in the reactor pulp:

$$
\mathrm{H}_{2} \mathrm{SO}_{4}+\mathrm{CaCO}_{3} \rightarrow \mathrm{CaSO}_{4} \downarrow+\mathrm{CO}_{2}+\mathrm{H}_{2} \mathrm{O}
$$

Since the consumption of $\mathrm{CaCO}_{3}$ in reactors 1 and 2 was significantly higher, this could lead to an increase in the mass yield of the bio-oxidation residue.

The phase analysis results were confirmed by XRD analysis (Table 5), which demonstrated the difference in the content of different minerals including pyrite and arsenopyrite and calcium sulfate-containing minerals in bio-oxidation residues obtained.

Table 5. Mineral composition of the concentrate and bio-oxidation residues (XRD).

\begin{tabular}{|c|c|c|c|c|c|c|c|}
\hline \multirow{3}{*}{ Mineral } & \multicolumn{7}{|c|}{ Content, $\%$} \\
\hline & \multirow{2}{*}{ Concentrate } & \multicolumn{3}{|c|}{$40{ }^{\circ} \mathrm{C}$} & \multicolumn{3}{|c|}{$50{ }^{\circ} \mathrm{C}$} \\
\hline & & Reactor 1 & Reactor 2 & Reactor 3 & Reactor 1 & Reactor 2 & Reactor 3 \\
\hline Pyrite $\left(\mathrm{FeS}_{2}\right)$ & 48 & 10 & 10 & 30 & $<1$ & 30 & 35 \\
\hline Arsenopyrite (FeAsS) & 9 & $<1$ & $<1$ & $<1$ & $<1$ & $<1$ & $<1$ \\
\hline Quartz $\left(\mathrm{SiO}_{2}\right)$ & 25 & 20 & 15 & 20 & 30 & 35 & 35 \\
\hline Mica & 18 & 10 & 10 & 5 & 15 & 25 & 20 \\
\hline Gypsum $\left(\mathrm{CaSO}_{4} \cdot 2 \mathrm{H}_{2} \mathrm{O}\right)$ & 0 & 55 & 65 & 45 & 15 & 0 & 0 \\
\hline Bassanite $\left(\mathrm{CaSO}_{4} \cdot 0.5 \mathrm{H}_{2} \mathrm{O}\right)$ & 0 & 0 & 0 & 0 & 40 & 10 & 10 \\
\hline Anhydrite $\left(\mathrm{CaSO}_{4}\right)$ & 0 & 5 & 0 & 0 & 0 & 0 & 0 \\
\hline
\end{tabular}

Thus, at $40^{\circ} \mathrm{C}$, both carbon dioxide and molasses significantly intensified bio-oxidation of the sulfide concentrate, which led to differences in the parameters of the pulp liquid phase as well as mineral oxidation rates (Tables 2-5). 


\subsubsection{Microbial Population Analysis}

Analysis of the microbial population showed that changes in the total number of microorganisms corresponded to changes in the parameters of the liquid phase (Figure 2a).

On the 10th day, the number of microorganisms in the liquid phase of the pulp was lower than at the beginning of the experiment $\left(1 \times 10^{8}\right.$ cells $/ \mathrm{mL}$ and $0.5-0.6 \times 10^{7}$ cells $/ \mathrm{mL}$, respectively). This may be explained by the fact that during the bio-oxidation of sulfide minerals, microorganisms at the beginning of the process are actively attached to mineral particles, which can lead to a decrease in the number of microorganisms in the liquid phase of the pulp at the initial stages of oxidation [43,44]. Moreover, a decrease in the microbial cell number might be caused by their lysis due to the inhibiting factors associated with a high pulp density: A high concentration of heavy metal ions, mechanical damage to cells with solid particles, saturation of the surface layers of bacteria with mineral particles that impede the entry of nutrients into the cell, and the release of exometabolites [45,46].

In reactors 1 and 2, microbial cell numbers in the liquid phase began to increase after 10 days of the bio-oxidation (Figure 2a, curves 1 and 2). In reactor 1, it reached a maximum on the 20th day $\left(9.2 \times 10^{8}\right.$ cells $\left./ \mathrm{mL}\right)$, after which it decreased (Figure 2a, curve 1$)$. It should be noted that in reactor 1 , the highest rate of iron and arsenic leaching, as well as a decrease in $\mathrm{pH}$ (Figure 1a,c,d, curve 1), was observed between 10 and 20 days, which corresponded to the interval in which the most rapid growth of the cell number in the liquid phase occurred. In reactor 2, the number of microorganisms began to increase after 10 days and grew until the end of the experiment. The growth rate of microbial cell number was maximum up to the 30th day, after which it decreased (Figure 2a, curve 2). In this case, the maximum rate of increase in cell number coincided with the maximum rate of iron leaching from the concentrate (Figure 1c,e curve 2), while the arsenic concentration rapidly increased in the range of 10-15 days, when no rapid increase in microbial cell number was observed in reactor 2 (Figure 1e, curve 2).

In reactor 3, a relatively rapid increase in the number of microbial cells began after 20 days of bio-oxidation, but after 30 days, there was practically no increase in the number of cells (Figure 2a, curve 3). In reactor 3, the maximum leaching rate did not correspond to the maximum growth rate of microbial cell number but was observed after 30 days of biooxidation (Figure 1c,e, curve 2). This phenomenon may be due to the consumption of the intermediates of the concentrate oxidation $\left(\mathrm{Fe}^{2+}\right.$, sulfur reduced compounds) accumulated over the first 20 days of the process by microorganisms in the period between 20 and 30 days of the experiment. It should be noted that the total number of microbial cells in control reactor 3 was 2-3 times lower than in reactors 1 and 2, where carbon dioxide and molasses were used as a carbon source, respectively (Figure 2a).

Thus, at $40^{\circ} \mathrm{C}$, the use of additional carbon sources led to an increase in the intensity of the concentrate bio-oxidation. Analysis of the effect of carbon sources on the number of microorganisms showed that the use of additional carbon sources led to an increase in the number of microorganisms in the reactor pulp. The introduction of additional carbon sources led to a reduction in the duration of the lag phase (in 1 and 2 reactors, active growth was observed after 10 days, while in control reactor 3 it began only after 20 days).

Molecular biological analysis of microbial population in the reactors revealed that the introduction of additional carbon sources also led to a change in the composition of the microbial communities of bioreactors. At $40{ }^{\circ} \mathrm{C}$, representatives of the genera Sulfobacillus, Acidithiobacillus, Acidiphilum, Acidiferrobacter, Leptospirillum, Ferroplasma, Cuniciliplasma, and uncultivated archaea of the A-plasma group were identified in microbial communities. At the same time, the shares of representatives of genera Sulfobacillus, Acidithiobacillus (Acidithiobacillus caldus), Leptospirillum, and Ferroplasma were significant. 


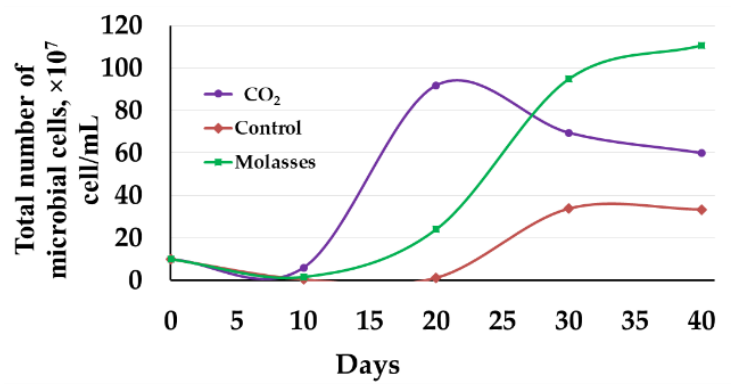

(a)

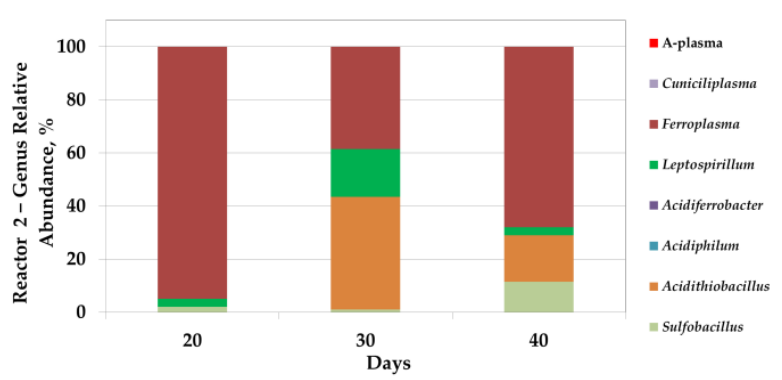

(c)

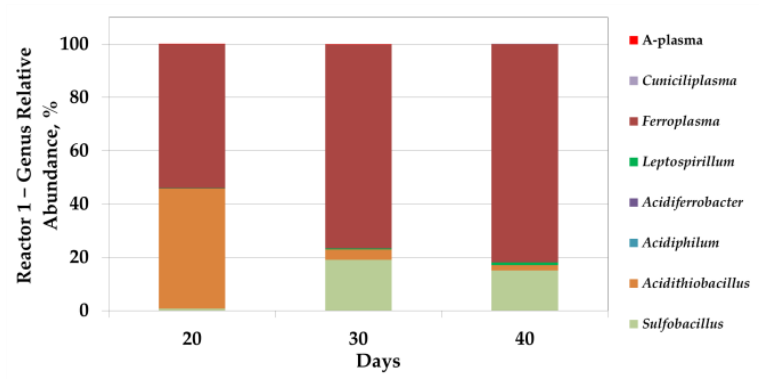

(b)

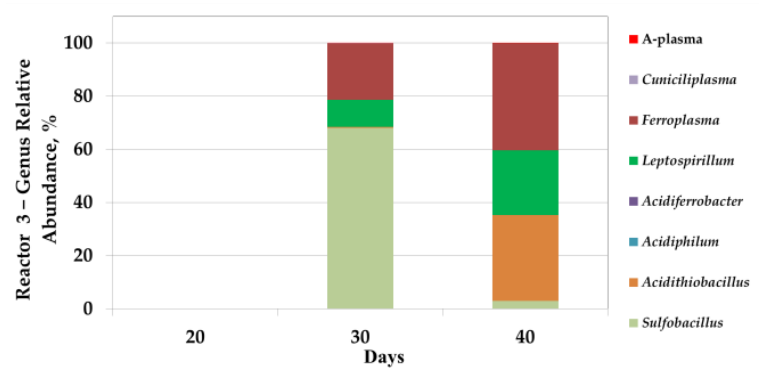

(d)

Figure 2. Analysis of microbial communities of bio-oxidation reactors $\left(40^{\circ} \mathrm{C}\right)$ : $(\mathbf{a})$ - total number of microbial cells $\left(10^{7}\right.$ cells $\left./ \mathrm{mL}\right)$; results of molecular biological analysis of microbial populations: (b) —reactor $1\left(\mathrm{CO}_{2}\right)$; (c) —reactor 2 (molasses); (d)-reactor 3 (control).

In reactor 1, on days 20,30, and 40, the proportion of Ferroplasma archaea was significant (Figure 2b). Obviously, in this reactor, $\mathrm{CO}_{2}$ supply allowed mixotrophic archaea to adapt to growth in the pulp, despite the absence of organic matter, due to carbon dioxide fixation that promotes their growth.

On the 20th day, which corresponded to the maximum number of microorganisms, the share of Acidithiobacillus caldus bacteria was also very significant.

On days 30 and 40, when the total number of microorganisms decreased, the proportion of the bacteria of the genus Sulfobacillus and Leptospirillum increased, while the proportion of Acidithiobacillus caldus decreased. Probably, the period of a decrease in the total number of microbial cells could be accompanied by partial lysis of cells of the autotrophic sulfur oxidizer Acidithiobacillus caldus, which led both to a decrease in the proportion of sequences of the genus Acidithiobacillus and to an increase in the proportion of mixotrophic bacteria of the genus Sulfobacillus after 30 days, which can consume lysis products of autotrophic microorganisms.

The proportion of archaea was also significant in reactor 2 (Figure 2c). On the 20th day, the proportion of the sequences from the genus Ferroplasma accounted for over $90 \%$.

On days 30 and 40, the proportion of bacteria Acidithiobacillus caldus, Sulfobacillus, and Leptospirillum increased. The predominance of the archea of the genus Ferroplasma in the microbial population of reactor 2 can be explained by the addition of molasses into the medium since representatives of the genus Ferroplasma is generally able to use organic matter as a source of carbon and energy [11].

Partial replacement of the archaea by the bacteria A. caldus and representatives of the genus Leptospirillum was observed on the 30th day of the experiment. By the end of the process, the share of Ferroplasma again increased due to the accumulation of exometabolites of autotrophic bacteria, which also may induce the growth of Ferroplasmaceae representatives [33]. It should be noted that up to 20 days the rate of iron leaching was relatively low, and after 20 days it increased. Possibly, this may indicate a potentially important role of the bacteria Acidithiobacillus caldus, Sulfobacillus, and Leptospirillum in pyrite leaching in comparison with archaea of the genus Ferroplasma. 
It was not possible to obtain a sufficient amount of biomass from the pulp sample collected from reactor 3 on the 20th day to isolate DNA for analysis according to the methods used, which was obviously due to the low number of microorganisms (Figure 2a, curve 3). On the 30th day, the proportions of the sequences of bacteria Sulfobacillus and Leptospirillum and archaea of the genus Ferroplasma were significant. On the 40th day, the proportion of sequences of bacteria Acidithiobacillus caldus and Leptospirillum, as well as archaea of the genus Ferroplasma increased, while the proportion of the bacteria of the genus Sulfobacillus decreased (Figure 2d).

\subsection{Bio-Oxidation under Thermophilic Conditons}

The results of the experiment on bio-oxidation of the concentrate at $50{ }^{\circ} \mathrm{C}$ are shown in Figures 3 and 4, as well as in Tables 2-5.

\subsubsection{Liquid Phase Analysis}

In contrast to the bio-oxidation at $40{ }^{\circ} \mathrm{C}$, at $50{ }^{\circ} \mathrm{C}$ only the addition of carbon dioxide made it possible to intensify the bio-oxidation process, while the addition of molasses to the medium affected the bio-oxidation to a lesser extent, which was demonstrated both by the parameters of the liquid phase of the pulp and by the oxidation rate of sulfide minerals (Tables 2-5).

The $\mathrm{pH}$ of the pulp liquid phase in reactor 1 rapidly decreased from 1.40 to 0.70 on the 20th day. Then, the $\mathrm{pH}$ in the reactor gradually increased due to the addition of $\mathrm{CaCO}_{3}$ and by the end of the experiment it was 1.72 (Figure 3a, curve 1). In reactor 2, in which molasses was added to the medium, and in control reactor 3 , the $\mathrm{pH}$ values decreased more slowly and it was possible to maintain it in the range 1.25-1.55 (Figure 3a, curves 2 and 3). In all reactors, $\mathrm{CaCO}_{3}$ was added to the slurry to maintain the $\mathrm{pH}$. In reactor 1, the consumption of $\mathrm{CaCO}_{3}$ was $456 \mathrm{~kg} / \mathrm{t}$ of concentrate, in reactor 2 it was $137 \mathrm{~kg} / \mathrm{t}$, while in control reactor 3 , it comprised $102 \mathrm{~kg} / \mathrm{t}$.

Changes in the Eh of the medium (Figure $3 b$ ), which reflect the activity of iron oxidation in the medium, corresponded to the changes in $\mathrm{pH}$ (Figure 3a). In reactor 1, Eh began to grow rapidly after 10 days and on the 12 th day of bio-oxidation exceeded $700 \mathrm{mV}$, and then was in the range of 724-795 $\mathrm{mV}$ (Figure 3b, curve 1). In reactors 2 and 3, the Eh values increased slowly compared to reactor 1 and reached maximum values on days 35-37 $(680-700 \mathrm{mV})$ (Figure 3b, curves 2 and 3), which was lower than the average Eh values in the reactor 1 (Figure $3 b$, curve 1 ).

The diagrams in Figure 3c,d show changes in the concentration of iron ions. Up to the 10th day of bio-oxidation, the total concentration of iron ions practically did not change in all reactors (Figure 3c, curves 1-3), while in all reactors the concentration of $\mathrm{Fe}^{2+}$ ions increased (Figure 3d, curves 1-3). After 9 days of bio-oxidation in reactor 1 , the concentration of $\mathrm{Fe}^{2+}$ ions rapidly decreased and remained low until the end of the experiment (less than $1.00 \mathrm{~g} / \mathrm{L}$ ), exceeding $1.00 \mathrm{~g} / \mathrm{L}$ only on days $20,35,37$, and 40 (Figure $3 \mathrm{~d}$, curve 1). This indicates that during the first 10 days of the experiment, the bio-oxidation activity was low, and accumulation of ferrous iron ions, as in the experiment at $40{ }^{\circ} \mathrm{C}$, occurred. After 10 days in reactor 1, the total concentration of iron ions $\mathrm{Fe}^{3+}$ and $\mathrm{Fe}^{2+}$ in the medium increased at a high rate, reaching a maximum $(56.00 \mathrm{~g} / \mathrm{L})$ by the end of the experiment (Table 2, Figure 3c, curve 1). In reactors 2 and 3, ferrous iron in the medium was slowly oxidized up to 27-28 days, after which its concentration rapidly decreased, but still remained sufficiently high until the end of the experiment (Table 2, Figure 3d, curves 2 and 3). The total concentration of iron ions $\mathrm{Fe}^{3+}$ and $\mathrm{Fe}^{2+}$ in reactors 2 and 3 in the medium increased slowly and at the end of the experiment were 6-7 times lower than in reactor 1 (Table 2, Figure 3c, curves 2 and 3).

The dynamics of changes in the concentration of arsenic in the medium were similar to the dynamics of changes in the concentration of iron ions (Figure 3d). In reactor 1, the arsenic concentration began to increase rapidly after 10 days of bio-oxidation, reaching a maximum $(11.4 \mathrm{~g} / \mathrm{L})$ on the 15 th day of bio-oxidation (Figure 1e, curve 1). Then the 
concentration of arsenic in the medium changed insignificantly (Figure 1e, curve 1). In reactors 2 and 3 , the arsenic concentrations in the medium increased more slowly and by the end of the experiment were 4-6 times lower than in reactor 1.

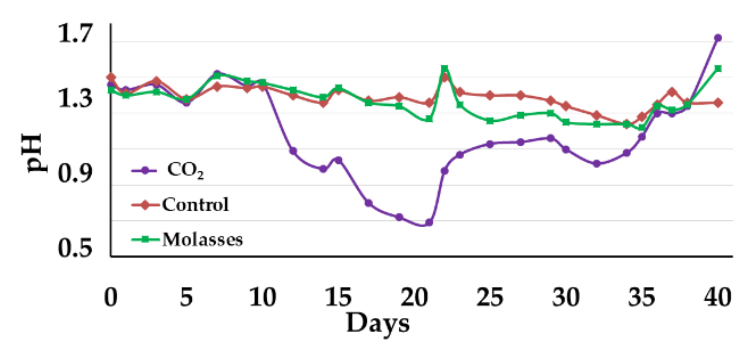

(a)

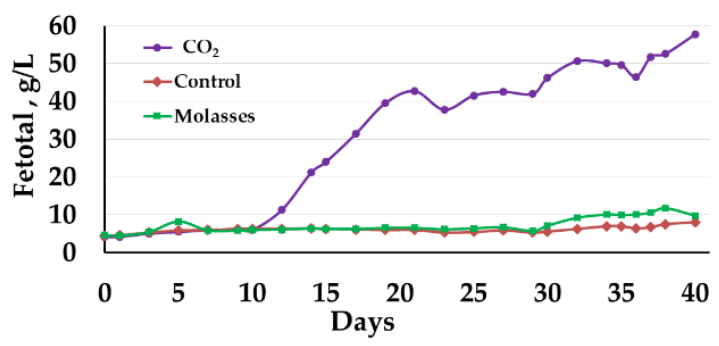

(c)

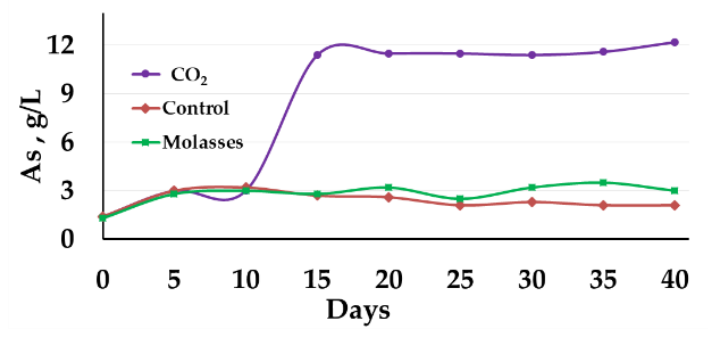

(e)

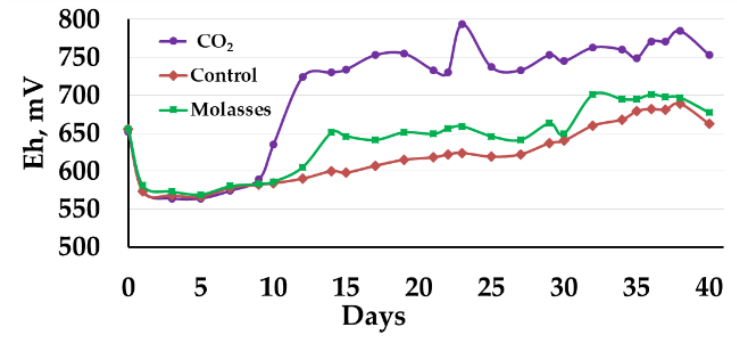

(b)

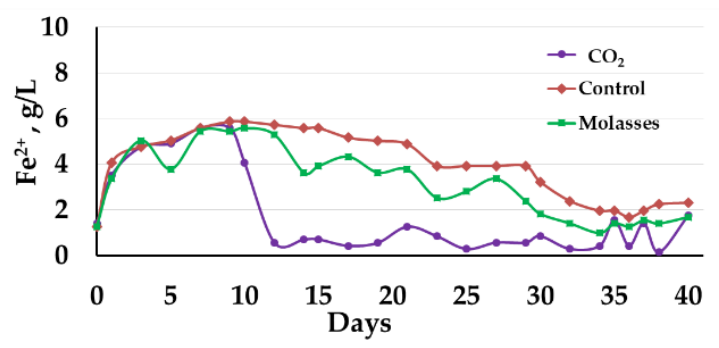

(d)

Figure 3. Changes in the liquid phase parameters during the bio-oxidation of the concentrate at $50{ }^{\circ} \mathrm{C}:(\mathbf{a})-\mathrm{pH}$; $(\mathbf{b})-$ Eh; (c)—total concentration of $\mathrm{Fe}^{3+}$ and $\mathrm{Fe}^{2+}$ ions (g/L); (d)—concentration of $\mathrm{Fe}^{2+}$ ions (g/L); (e)—concentration of $\operatorname{arsenic}(\mathrm{g} / \mathrm{L})$.

\subsubsection{Solid Residue Analysis}

Tables 3 and 4 summarize the results of the phase analysis of the solid phase. It was shown that the oxidation state of sulfide sulfur was the highest in reactor 1 , as well as during bio-oxidation at $40{ }^{\circ} \mathrm{C}$, while in reactors 2 and 3 , the oxidation rate of sulfide sulfur was more than 3-5 times lower.

The oxidation rate of pyrite in reactor 1 was the highest and higher than that in the experiment at $40^{\circ} \mathrm{C}$. Obviously, this may be due to that at a higher temperature the mineral was oxidized at a higher rate, and the use of carbon dioxide made it possible to create favorable conditions for bio-oxidation since microbial population promoting active oxidation of sulfide minerals formed under these conditions.

At the same time, the oxidation rates of pyrite in reactors 2 and 3 were low (about $20 \%$ and $10 \%$, respectively). Arsenopyrite oxidation rate was high in all reactors, but in reactor 1 it was higher. It should be noted that the mass yield of the solid residue of concentrate bio-oxidation in reactor 1 was lower, despite the greater amount of added calcium carbonate, while in reactors 2 and 3 it was close to $100 \%$. The phase analysis results were confirmed by XRD analysis (Table 5).

Thus, at $50^{\circ} \mathrm{C}$, the use of carbon dioxide significantly affected the rate of bio-oxidation, while the use of molasses did not significantly affect the bio-oxidation of the concentrate. 


\subsubsection{Microbial Population Analysis}

Analysis of the microbial population showed that changes in the total number of microorganisms generally corresponded to changes in the parameters of the liquid phase and the results of bio-oxidation of the concentrate. However, the number of microorganisms in reactors at $50{ }^{\circ} \mathrm{C}$ was several times lower than at $40{ }^{\circ} \mathrm{C}$ (Figure 4a). In reactor 1 , the number of microbial cells in the liquid phase began to increase rapidly after 15 days and reached a maximum at $20-25$ days $\left(2.1-2.5 \times 10^{8}\right.$ cells $\left./ \mathrm{mL}\right)$, after which it began to decrease (Figure $4 a$, curve 1). In reactors 2 and 3 , the number of microorganisms began to increase after 20 days but was rather low (2.1 and $1.2 \times 10^{8}$ cells $/ \mathrm{mL}$, respectively).

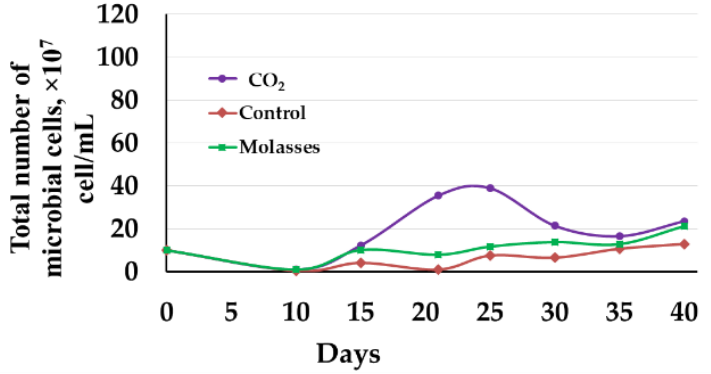

(a)

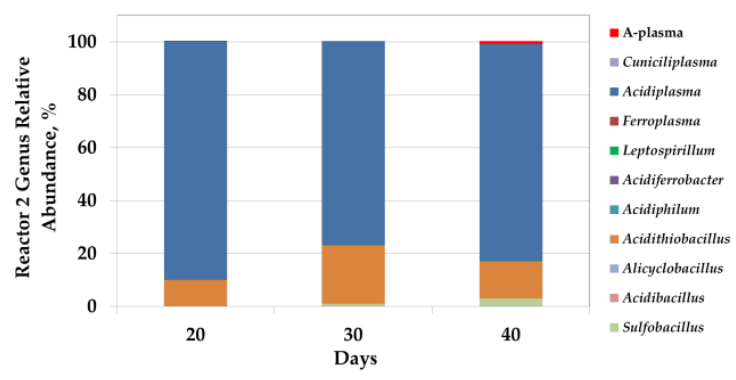

(c)

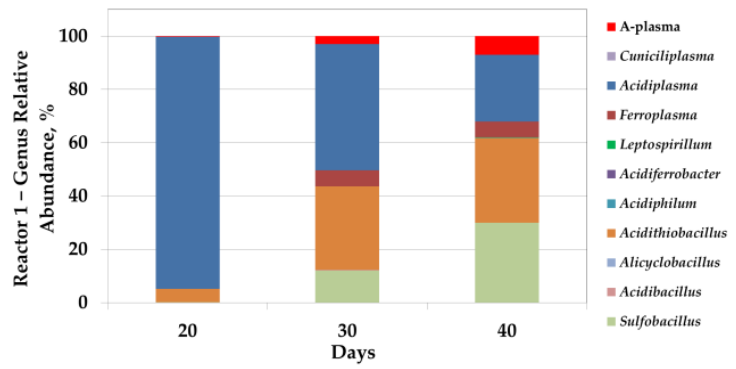

(b)

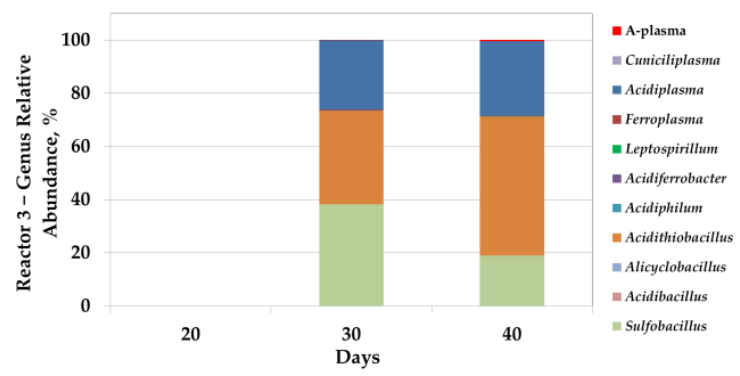

(d)

Figure 4. Analysis of microbial communities of bio-oxidation reactors $\left(50{ }^{\circ} \mathrm{C}\right)$ : $(\mathbf{a})$ - total number of microbial cells $\left(10^{7}\right.$ cells $\left./ \mathrm{mL}\right)$; results of molecular biological analysis of microbial populations: (b)—reactor $1\left(\mathrm{CO}_{2}\right)$; (c) -reactor 2 (molasses); (d)-reactor 3 (control).

Molecular biological analysis revealed that the introduction of additional carbon sources into the bioreactor pulp also led to a change in the composition of the microbial communities of the bioreactors. At $50{ }^{\circ} \mathrm{C}$, representatives of the genera Sulfobacillus, Acidibacillus, Alicyclobacillus, Acidithiobacillus, Acidiphilum, Acidiferrobacter, Leptospirillum, Ferroplasma, Acidiplasma, Cuniciliplasma, and uncultivated archaea A-plasma were revealed in microbial communities. The shares of representatives of bacteria Sulfobacillus and Acidithiobacillus (Acidithiobacillus caldus) and archaea of the genera Ferroplasma and Acidiplasma, as well as the uncultivated group A-plasma were significant, while proportions of the sequences of other groups were comparatively low.

In reactor 1 , on days 20,30, and 40, there was a significant proportion of archaea from the genus Acidiplasma (95-25\%) (Figure 4b). On the 20th day, which corresponded to the maximum number of microbial cells, the proportion of bacteria Acidithiobacillus caldus was also relatively high (5\%). On days 30 and 40 , during which the total number of microorganisms decreased, the proportion of the bacteria Sulfobacillus and Acidithiobacillus caldus increased, while share of the archaea Ferroplasma and A-plasma decreased. It should be noted that up to 20 days the rate of iron and arsenic leaching was maximum, and after 20 days the concentration of arsenic in the medium stabilized, while the rate of iron leaching decreased, but the iron concentration continued to increase. It is possible that in the period from 10 to 20 days arsenopyrite and the relatively easily oxidized fraction of pyrite were 
intensively oxidized, while after 20 days further oxidation of the concentrate minerals occurred, which may indicate a potentially large role of the bacteria Acidithiobacillus caldus and Sulfobacillus, which share has increased significantly, in the oxidation of the most resistant minerals.

In reactor 2, the proportion of archaea of the genus Acidiplasma was significant (Figure 4c). On days 20,30, and 40, the proportion of the sequences of the archaea of the genus Acidiplasma accounted for 90,77, and $82 \%$, respectively. The predominance in the microbial community of reactor 2 archaea of the genus Acidiplasma can be explained by the introduction of molasses into the medium since representatives of this genus are obviously iron-oxidizing mixotroph and their growth depends on the presence of an organic carbon source in the medium. Previously, it was shown that the number of archaea of the genus Acidiplasma in bio-oxidation reactor communities increased significantly when an organic carbon source was introduced into the environment [20].

It was not possible to obtain sufficient biomass from the pulp sample collected from reactor 3 on the 20th day to isolate DNA for analysis, which was obviously due to the low number of microorganisms, as well as in the experiment at $40^{\circ} \mathrm{C}$ (Figure $4 \mathrm{a}$, curve 3 ). On days 30 and 40, the proportions of the sequences of bacteria Sulfobacillus and bacteria Acidithiobacillus caldus and archaea of the genus Acidiplasma were significant.

Analysis of the results of the analysis of microbial communities of bio-oxidation reactors at $50{ }^{\circ} \mathrm{C}$ and their comparison with the results of bio-oxidation showed that the addition of molasses led to a relatively insignificant increase in the total number of microorganisms and to an increase in the proportion of archaea of the genus Acidiplasma, which did not lead to an intensification of the bio-oxidation process.

\section{Discussion}

The results obtained in this work showed that the use of both inorganic (carbon dioxide) and organic (molasses) additional carbon sources made it possible to intensify the growth of microorganisms and the leaching process. It was demonstrated that the use of both investigated carbon sources led to an increase in the number of microorganisms in the liquid phase of the bioreactor pulp. At the same time, the use of carbon dioxide led to a more rapid increase in the number of microorganisms and to a more significant reduction in the lag phase, which was accompanied by a more rapid leaching of iron from the concentrate.

At $40{ }^{\circ} \mathrm{C}$, the use of molasses also made it possible to increase the rate of bio-oxidation of the concentrate; however, it should be noted that the rate of iron leaching in this case increased more slowly than when using carbon dioxide. The leaching rate of arsenic was high using both carbon sources. At $50^{\circ} \mathrm{C}$, only carbon dioxide addition made it possible to significantly increase the rate of sulfide concentrate bio-oxidation.

Obviously, the effect of carbon sources on the process of bio-oxidation of sulfide concentrate was due to their effect on microbial communities that developed in bio-oxidation reactors. At $40{ }^{\circ} \mathrm{C}$, the total number of microorganisms when using additional carbon sources was several times higher than in the control experiment.

At the same time, differences were observed not only in the number of microorganisms, but also in the composition of microbial populations. In reactors 1 and 2, the proportion of archaea of the genus Ferroplasma was higher than in the control reactor. In reactor 1, where carbon dioxide was used, there was a relatively high proportion of bacteria A. caldus (at the beginning of the process) and Sulfobacillus (at the end of the process). It is likely that the supply of carbon dioxide to the pulp allowed autotrophic bacteria $A$. caldus to develop at the initial stage of the process, and the accumulation of its metabolites and, possibly, cell lysis products in the medium led to an increase in the proportion of mixoand heterotrophic iron-oxidizing microorganisms in the population at subsequent stages.

When adding molasses to the medium, the proportion of archaea sequences of the genus Ferroplasma was the highest, but then the proportion of acidophilic bacteria Leptospirillum, A. caldus, and Sulfobacillus also increased. Thus, despite the differences in the 
composition of microbial communities revealed under different conditions, changes in the composition of microbial populations were observed during bio-oxidation, and it is obvious that different microorganisms could predominate at different stages of bio-oxidation. Interestingly, when an organic carbon source was added to the medium at the end of the process, autotrophic microorganisms developed. It is likely that at the beginning of the process, there was an accumulation of components in the oxidation products that contributed to their development. For example, the predominance of iron-oxidizing archaea of the genus Ferroplasma, which require an organic carbon source, in reactor 2 could lead to the accumulation of elemental sulfur in the solid phase during the bio-oxidation of arsenopyrite [12,47], that resulted in an increase in the proportion of autotrophic sulfur-oxidizing bacteria A. caldus. In addition, in reactors 1 and 2, at the end of the experiment, there was an increase in the proportion of bacteria Leptospirillum and Sulfobacillus, which can play an important role in the oxidation of pyrite [42,48].

It should be noted that in reactor 3, where the source of carbon for the microbial community could only be carbon dioxide, which is introduced with the aeration, there was a significant proportion of acidophilic iron and sulfur-oxidizing bacteria. Despite this, the intensity of bio-oxidation in the control reactor 3 was the lowest, which is obviously due to the low total number of microorganisms.

At $50{ }^{\circ} \mathrm{C}$, the use of carbon dioxide significantly affected the rate of bio-oxidation, while the effect of molasses on the bio-oxidation of the concentrate was comparatively low. In contrast to bio-oxidation at $40{ }^{\circ} \mathrm{C}$, at $50{ }^{\circ} \mathrm{C}$ the proportions of the genera Leptospirillum and Ferroplasma were low, while archaea of the genus Acidiplasma were one of the predominant groups in all reactors that may be explained by higher temperature optimum of the representatives of genus Acidiplasma in comparison to Leptospirillum and Ferroplasma representatives [1,49].

In reactor 1, where carbon dioxide was used, the proportion of the bacteria Sulfobacillus and Acidithiobacillus caldus was high on days 30 and 40, despite Acidiplasma sequences being predominant at the beginning of the process.

In reactor 2, where organic carbon source was used, the proportion of archaea of the genus Acidiplasma was the highest that may be explained by its dependence on the organic carbon source. It is corresponded to the data obtained in our previous work, as it was shown that the number of archaea of the genus Acidiplasma in bio-oxidation reactor increased significantly when an organic carbon source (yeast extract) was used to increase the bio-oxidation rate [20].

In reactor 3, where no additional source of carbon for the microbial population was used bio-oxidation rate was the lowest, which is obviously due to the lowest total number of microorganisms. It may suggest that at higher temperatures, the activity of the microbial population depended on the presence of additional carbon sources to a greater extent. This fact may be explained by the decrease in $\mathrm{CO}_{2}$ solubility with an increasing temperature that led to the deficiency in dissolved $\mathrm{CO}_{2}$ at $50{ }^{\circ} \mathrm{C}$ in the absence of additional carbon sources.

It should be noted that a long lag phase was observed in all experiments (10-25 days). This may be due to the inhibitory effect of high pulp density ( $20 \%$ solid) on the cells of the main groups of bacteria that oxidize sulfide minerals in this work [45]. The use of additional carbon sources made it possible to reduce the duration of the lag phase.

Thus, it was shown that the use of various carbon sources made it possible to significantly increase the intensity of bio-oxidation of the sulfide concentrate since it influenced the number of microorganisms and the composition of microbial populations. Obviously, in the processes of bio-oxidation of sulfide concentrates, the availability of carbon for auto-, mixo-, and heterotrophic microorganisms can be a limiting factor, and the study of the effect of various carbon sources on the intensity of the bio-oxidation process is a promising direction for the development of biohydrometallurgical technologies.

Indeed, the use of additional carbon sources may lead to additional costs to equip the reactors with additional nutrients (both carbon dioxide and organic nutrients). At the same time, the application of additional carbon nutrition may allow resolving a key issue 
in industrial-scale bio-oxidation processes-inhibition of bio-oxidation activity due to the overheating of bioleach reactor pulp. In our work, it was shown that bio-oxidation may be performed efficiently both at 40 and $50{ }^{\circ} \mathrm{C}$ when using carbon dioxide supply. As carbon dioxide was shown to be profitably used in industrial-scale processes [6], it may be also successfully used to prevent the negative effects of overheating as well as to decrease costs when applying cooling systems since $\mathrm{CO}_{2}$ supply provided effective bio-oxidation under both mesophilic and thermophilic conditions.

In the present work, the experiments were performed in a batch mode, while more reliable results - from the perspective of modeling industrial-scale processes-may be obtained in continuous laboratory trials. Nevertheless, the results obtained provide strong evidence of the hypothesis that additional carbon nutrition can significantly affect biooxidation efficiency and decrease the negative effect of temperature rise. Thus, based on the results of the present work, further continuous laboratory and pilot tests may be designed.

\section{Conclusions}

Based on the findings through the bath laboratory tests, it was shown that the use of various carbon sources made it possible to increase the intensity of pyrite-arsenopyrite concentrate bio-oxidation since it affected microbial populations performing the process. The application of carbon dioxide provided more effective bio-oxidation at different temperatures $\left(40\right.$ and $50{ }^{\circ} \mathrm{C}$ ) in comparison to the control tests. Thus, carbon dioxide supply may be proposed as an effective approach to minimize the negative effects of temperature rise during bio-oxidation processes as well as to decrease costs for cooling of industrialscale reactors.

Author Contributions: Conceptualization, A.B.; methodology, A.B.; investigation, A.B., A.N., Y.E. and V.M.; writing—original draft preparation, A.B.; writing-review and editing, A.B., A.N., Y.E. and V.M.; supervision, A.B.; project administration, A.B.; funding acquisition, A.B. All authors have read and agreed to the published version of the manuscript.

Funding: The study was supported by the Ministry of Science and Higher Education of the Russian Federation.

Institutional Review Board Statement: Not applicable.

Informed Consent Statement: Not applicable.

Conflicts of Interest: The authors declare no conflict of interest.

\section{References}

1. Johnson, D.B. Biomining-Biotechnologies for extracting and recovering metals from ores and waste materials. Curr. Opin. Biotechnol. 2014, 30, 24-31. [CrossRef]

2. Johnson, D.B. The Evolution, Current Status, and Future Prospects of Using Biotechnologies in the Mineral Extraction and Metal Recovery Sectors. Minerals 2018, 8, 343. [CrossRef]

3. Mahmoud, A.; Cezac, P.; Hoadley, A.F.A.; Contaminea, F.; D’Hugues, P. A review of sulfide minerals microbially assisted leaching in stirredtank reactors. Int. Biodeteriorat. Biodegrad. 2017, 119, 118-146. [CrossRef]

4. Marsden, J.O.; House, C.I. The Chemistry of Gold Extraction, 2nd ed.; Society for Mining, Metallurgy, and Exploration, Inc.: Littleton, CO, USA, 2006; 625p.

5. Thomas, K.G. Pressure oxidation overview. In Developments in Mineral Processing, Advances in Gold Ore Processing; Adams, M.D., Wills, B.A., Eds.; Elsevier B.V: Amsterdam, The Netherlands, 2006; Volume 15, pp. 346-369.

6. van Aswegen, P.C.; van Niekerk, J.; Olivier, W. The BIOX process for the treatment of refractory gold concentrate. In Biomining; Rawlings, D.E., Johnson, B.D., Eds.; Springer: Berlin, Germany, 2007; pp. 1-35. [CrossRef]

7. Gericke, M.; Neale, J.W.; van Staden, P.J. A Mintek perspective of the past 25 years in minerals bioleaching. J. S. Afr. Inst. Min. Metall. 2017, 109, 567-585.

8. Belyi, A.V.; Chernov, D.V.; Solopova, N.V. Development of BIONORD ${ }^{\circledR}$ technology on Olimpiada deposit refractory arsenic-gold ores treatment in conditions of Extreme North. Hydrometallurgy 2018, 179, 188-191. [CrossRef]

9. Rawlings, D.E.; Coram, N.J.; Gardner, M.N.; Deane, S.M. Thiobacillus caldus and Leptospirillum ferrooxidans are widely distributed in continuous flow biooxidation tanks used to treat a variety of metal containing ores and concentrates. In Biohydrometallurgy and the Environment: Toward the Mining of the 21st Century. Part A; Amils, R., Ballester, A., Eds.; Elsevier: Amsterdam, The Netherlands, 1999; pp. 777-786. [CrossRef] 
10. Coram, N.J.; Rawlings, D.E. Molecular relationship between two groups of the genus Leptospirillum and the finding that Leptospirillum ferriphilum sp. nov. dominates South African commercial biooxidation tanks that operate at $40{ }^{\circ} \mathrm{C}$. Appl. Environ. Microbiol. 2002, 68, 838-845. [CrossRef] [PubMed]

11. Okibe, N.; Gericke, M.; Hallberg, K.B.; Johnson, D.B. Enumeration and characterization of acidophilic microorganisms isolated from a pilot plant stirred tank bioleaching operation. Appl. Environ. Microbiol 2003, 69, 1936-1943. [CrossRef]

12. Dopson, M.; Lindstrom, E.B. Analysis of community composition during moderately thermophilic bioleaching of pyrite, arsenical pyrite, and chalcopyrite. Microb. Ecol. 2004, 48, 19-28. [CrossRef]

13. Morin, D.H.R.; d'Hugues, P. Bioleaching of a cobalt containing pyrite in stirred reactors: A case study from laboratory scale to industrial application. In Biomining; Rawlings, D.E., Johnson, B.D., Eds.; Springer: Berlin, Germany, 2007; pp. 35-55. [CrossRef]

14. Spolaore, P.; Joulian, C.; Gouin, J.; Ibáñez, A.; Auge, T.; Morin, D.; d'Hugues, P. Bioleaching of an organic-rich polymetallic concentrate using stirred-tank technology. Hydrometallurgy 2009, 99, 137-143. [CrossRef]

15. Spolaore, P.; Joulian, C.; Gouin, J.; Morin, D.; d' Hugues, P. Relationship between bioleaching performance, bacterial community structure and mineralogy in the bioleaching of a copper concentrate in stirred-tank reactors. Appl. Microbiol. Biotechnol. 2010, 89, 441-448. [CrossRef] [PubMed]

16. Zeng, W.; Qiu, G.; Zhou, H.; Peng, J.; Chen, M.; Tan, S.N.; Chao, W.; Liu, X.; Zhang, Y. Community structure and dynamics of the free and attached microorganisms during moderately thermophilic bioleaching of chalcopyrite concentrate. Bioresour. Technol. 2010, 101, 7068-7075. [CrossRef] [PubMed]

17. Wang, Y.; Su, L.; Zhang, L.; Zeng, W.; Wu, J.; Wan, L.; Qiu, G.; Chen, X.; Zhou, H. Bioleaching of chalcopyrite by defined mixed moderately thermophilic consortium including a marine acidophilic halotolerant bacterium. Bioresour. Technol. 2012, 121, 348-354. [CrossRef]

18. van Hille, R.P.; van Wyk, N.; Froneman, T.; Harrison, S.T.L. Dynamic evolution of the microbial community in BIOX leaching tanks. Adv. Mater. Res. 2013, 825, 331-334. [CrossRef]

19. Kondrat'eva, T.F.; Pivovarova, T.A.; Bulaev, A.G.; Moshchanetskii, P.V.; Tsaplina, I.A.; Grigor'eva, N.V.; Zhuravleva, A.E.; Melamud, V.S.; Belyi, A.V. Selection of a community of acidochemolithotrophic microorganisms with a high oxidation rate of pyrrhotite-containing sulphide ore flotation concentrate. Appl. Biochem. Microbiol. 2013, 49, 495-501. [CrossRef]

20. Muravyov, M.I.; Bulaev, A.G. Two-step oxidation of a refractory gold-bearing sulfidic concentrate and the effect of organic nutrients on its biooxidation. Miner. Eng. 2013, 45, 108-114. [CrossRef]

21. Wang, Y.; Zeng, W.; Qiu, G.; Chen, X.; Zhou, H. A moderately thermophilic mixed microbial culture for bioleaching of chalcopyrite concentrate at high pulp density. Appl. Environ. Microbiol. 2014, 80, 741-750. [CrossRef]

22. Hedrich, S.; Guézennec, A.-G.; Charron, M.; Schippers, A.; Joulian, C. Quantitative monitoring of microbial species during bioleaching of a copper concentrate. Front. Microbiol. 2016, 7, 20441. [CrossRef] [PubMed]

23. Bulaev, A.; Belyi, A.; Panyushkina, A.; Solopova, N.; Pivovarova, T. Microbial population of industrial biooxidation reactors. Solid State Phenom. Submitt. 2017, 262, 48-52. [CrossRef]

24. Bulaev, A.; Melamud, V.; Boduen, A. Bioleaching of non-ferrous metals from arsenic-bearing sulfide concentrate. Solid State Phenom. 2020, 299, 1064-1068. [CrossRef]

25. Karavaiko, G.I.; Dubinina, G.A.; Kondrateva, T.F. Lithotrophic microorganisms of the oxidative cycles of sulfur and iron. Microbiology (Mikrobiologiya) 2006, 75, 512-545. [CrossRef]

26. Muravyov, M.I.; Bulaev, A.G. A two-step process for the treatment of refractory sulphidic concentrate. Adv. Mater. Res. 2013, 825, 246-249. [CrossRef]

27. Schippers, A. Microorganisms involved in bioleaching and nucleic acid-based molecular methods for their identification and quantification. In Microbial Processing of Metal Sulfides; Donati, E.R., Sand, W., Eds.; Springer: Dordrecht, The Netherlands, 2007; pp. 3-33. [CrossRef]

28. Gonzalez-Tori, E.; Llobet-Brossa, E.; Casamayor, E.O.; Amann, R.; Amils, R. Microbial ecology of an extreme acidic environment, the Tinto River. Appl. Environ. Microbiol. 2003, 69, 4853-4865. [CrossRef] [PubMed]

29. Druschel, G.K.; Baker, B.J.; Gihring, T.H.; Banfield, J.F. Acid mine drainage biogeochemistry at Iron Mountain. Calif. Geochem. Trans. 2004, 5, 13-32. [CrossRef]

30. Schnaitman, C.; Lundgren, D.G. Organic compounds in the spent medium of Ferrobacillus ferrooxidans. Can. J. Microbiol 1965, 11, 23-27. [CrossRef] [PubMed]

31. Borichewski, R.M. Keto acids as growth-limiting factors in autotrophic growth of Thiobacillus thiooxidans. J. Bacteriol 1967, 93, 597-599. [CrossRef]

32. Okibe, N.; Johnson, D.B. Biooxidation of pyrite by defined mixed cultures of moderately thermophilic acidophiles in pH-controlled bioreactors: Significance of microbial interactions. Biotechnol. Bioeng. 2004, 87, 574-583. [CrossRef]

33. Nancucheo, I.; Johnson, D.B. Production of glycolic acid by chemolithotrophic iron- and sulfur-oxidizing bacteria and its role in delineating and sustaining acidophilic sulfide mineral-oxidizing consortia. Appl. Environ. Microbiol. 2010, 76, 461-467. [CrossRef]

34. Bulaev, A.G. Biooxidation of refractory pyrite-arsenopyrite gold bearing sulfide concentrate. In Proceedings of the19th International Multidisciplinary Scientific GeoConference (SGEM 2019), Albena, Bulgaria, 28 June-7 July 2019; Volume 6.3, pp. 67-74. [CrossRef]

35. Reznikov, A.A.; Mulikovskaya, E.P.; Sokolov, I.Y. Metody analiza prirodnykh vod (Methods for Analysis of Natural Waters); Nedra: Moscow, Russia, 1970; 140p. (In Russian) 
36. Surovskaya, I.A.; Titov, V.I.; Brodskaya, V.M.; Vasil'ev, P.I.; Lipshits, B.M.; Elentukh, B.M. Tekhnicheskii analiz tsvetnoi metallurgii (Technical Analysis in Nonferrous Metallurgy); Metallurgizdat: Moscow, Russia, 1957; p. 567. (In Russian)

37. Filippova, N.A. Fazovyi analiz rud i produktov ikh pererabotki (Phase Analysis of Ores and Products of Their Processing); Khimiya: Moscow, Russia, 1975; 280p. (In Russian)

38. Pimenov, N.V.; Merkel, A.Y.; Samylina, O.S.; Kanapatskii, T.A.; Tikhonova, E.N.; Vlasova, M.A.; Tarnovetskii, I.Y.; Malakhova, T.V. Structure of Microbial Mats in the Mramornaya Bay (Crimea) Coastal Areas. Microbiology (Mikrobiologiya) 2018, 87, 681-691. [CrossRef]

39. Das, B. Theoretical study of formation of secondary arsenic minerals: Scorodite and pharmacosiderite. ACS Earth Space Chem. 2019, 3, 192-201. [CrossRef]

40. Deng, S.; Gu, G.; He, G.; Li, L. Catalytic effect of pyrite on the leaching of arsenopyrite in sulfuric acid and acid culture medium. Electrochim. Acta 2018, 263, 8-16. [CrossRef]

41. Xu, J.-N.; Shi, W.-G.; Ma, P.-C.; Lu, L.-S.; Chen, G.-M.; Yang, H.-Y. Corrosion behavior of a pyrite and arsenopyrite galvanic pair in the presence of sulfuric acid, ferric ions and HQ0211 bacterial strain. Minerals 2019, 9, 169. [CrossRef]

42. Rawlings, D.E.; Tributsch, H.; Hansford, G. Reasons why 'Leptospirillum'-like species rather than Thiobacillus ferrooxidans are the dominant iron-oxidizing bacteria in many commercial processes for the biooxidation of pyrite and related ores. Microbiology 1999, 145, 5-13. [CrossRef] [PubMed]

43. Gonzalez, R.; Gentina, J.C.; Acevedo, F. Attachment behaviour of Thiobacillus ferrooxidans cells to refractory gold concentrate particles. Biotechnol. Lett. 1999, 21, 715-718. [CrossRef]

44. Lizama, H.M.; Fairweather, M.J.; Dai, Z.; Allegretto, T.D. How does bioleaching start? Hydrometallurgy 2003, 69, 109-1161. [CrossRef]

45. Deveci, H. Effect of particle size and shape of solids on the viability of acidophilic bacteria during mixing in stirred tank reactors. Hydrometallurgy 2004, 71, 385-396. [CrossRef]

46. Melamud, V.S.; Pivovarova, T.A. Specific features of the growth of the type strain of Sulfobacillus thermosulfidooxidans in medium 9K. Appl. Biochem. Microbiol. 1998, 34, 314-315.

47. Vaughan, D.J.; Corkhill, C.L. Mineralogy of Sulfides. Elements 2017, 13, 81-87. [CrossRef]

48. Bulaev, A.G. Effect of organic carbon source on pyrite biooxidation by moderately thermophilic acidophilic microorganisms. Microbiology (Moscow) 2020, 89, 301-308. [CrossRef]

49. Golyshina, O.V.; Yakimov, M.M.; Lünsdorf, H.; Ferrer, M.; Nimtz, M.; Timmis, K.N.; Wray, V.; Tindall, B.J.; Golyshin, P.N. Acidiplasma aeolicum gen. nov., sp. nov., a euryarchaeon of the family Ferroplasmaceae isolated from a hydrothermal pool, and transfer of Ferroplasma cupricumulans to Acidiplasma cupricumulans comb. nov. Int. J. Syst. Evol. Microbiol. 2009, 59, $2815-2824$. [CrossRef] 